УДК 636.087 .7

doi: $10.36359 /$ scivp.2019-20-2.06

\title{
ЕФЕКТИВНІСТЬ ЗАСТОСУВАННЯ ТЕХНОЛОГІЧНОЇ КОРМОВОЇ ДОБАВКИ ГЕПАСОРБЕКС СТОСОВНО ДЕЯКИХ МІКОТОКСИНІВ
}

\author{
Т. Р. Левицький', канд. с.-г. наук
}
Державний науково-дослідний контрольний інститут ветеринарних препаратів та кормових добавок, вул. Донецька, 11, м. Львів, 79019, Україна

\begin{abstract}
Проведено вивчення ефективності застосування технологічної кормової добавки Гепасорбекс із функціональної групи речовини для зменшення забруднення кормів мікотоксинами в лабораторних умовах. Метою роботи було встановлення in vitro ефективності застосування кормової добавки Гепасорбекс иляхом підтвердження їі здатності стримувати або знижувати поглинання мікотоксинів (фумонізинів та Т2 токсину). Ефективність специфічної дї кормової добавки визначали кількісно при різних значеннях $\mathrm{pH}$, що імітують зміну кислотності середовища в травному каналі тварин. Дослідження проведено у два етапи: скринінговий - з використанням розчину мікотоксину та основний - з використанням кормової суміші, який містив мікотоксини. На скринінговому етапі кормову добавку Гепасорбекс вносили у буферні розчини, які містили відповідно фумонізини та Т2-токсин у кількості 200 мкг/2. В основному досліді досліджувану кормову добавку Гепасорбекс вносили у пробу кормової суміші з розрахунку 1, 2, 5 г/кг і ретельно гомогенізували пробу. Проведено визначення величини адсорбиії (в кислому середовищі) та величину десорбиії (в лужному середовищі). Критерієм оцінки ефективності був практичний коефіцієнт корисної дї̈, який обраховувався иляхом встановлення різниці між кількістю внесеного мікотоксину та кількістю адсорбованого мікотоксину після інкубаиії у кислому середовищі з врахуванням величини десорбиії після інкубації у лужному середовищі. Встановлено, щзо при скринінгових дослідженнях практичний коефіиієнт корисної дії кормової добавки стосовно фумонізинів становив 78,0\%, стосовно Т2 токсину - 70,5 \%. В основному досліді виявлено, щуо практичний коефіиієнт корисної дії кормової добавки в залежності від дози становив стосовно фумонізинів 69,1-72,3\%, стосовно Т2 токсину - 38,2 - 41,6 \%. Отримані результати підтверджують те, щзо досліджувана кормова добавка володіє вираженими адсорбційними властивостями стосовно фумонізинів та Т2-токсину.
\end{abstract}

Ключові слова: ФУМОНІЗИНИ, Т2-ТОКСИН, АДСОРБЦІЯ, ДЕСОРБЦІЯ.

У сучасних умовах виробництво повнораціонних кормів неможливе без використання кормових добавок. Згідно із Законом України «Про безпечність та гігієну кормів», кормові добавки - це речовини, мікроорганізми або суміші, інші, ніж кормовий матеріал або премікси, які спеціально додаються до корму або води з метою виконання однієї чи декількох 3 таких функцій: задоволення поживних потреб тварин, забезпечення сприятливого впливу на характеристики кормів, продуктів тваринного походження, екологічні наслідки тваринницької діяльності, продуктивність та благополуччя тварин, зокрема шляхом впливу на шлунковокишкову флору та засвоюваність кормів чи колір декоративних рибок та птахів, здійснення кокцидіостатичної чи гістомоностатичної дії. Кормові добавки поділяються на п’ять категорій. У межах відповідної категорії кормова добавка може бути віднесена до однієї або декількох функціональних груп [Zakon Ukrayiny` «Pro bezpeku ta gigiyenu kormiv»].

${ }^{1}$ Науковий консультант - д-р ветеринарних наук, професор, академік НААН І. Я. Коцюмбас 
Закон України «Про безпечність та гігієну кормів» передбачає, що використання будьякою фізичною чи юридичною особою кормової добавки для виробництва корму та/або для здійснення iï обігу, а також обігу корму, виробленого з іiї використанням, можливе лише за умови, що така кормова добавка зареєстрована в Україні. У Законі встановлено загальні вимоги до реєстрації нових кормових добавок та необхідні матеріали, які повинні бути подані для реєстрації. Зокрема, у статті 17 цього Закону передбачено необхідність подання матеріалів випробувань, що підтверджують відповідність кормової добавки одній з таких вимог:

1) позитивно впливати на характеристики корму;

2) позитивно впливати на характеристики продуктів тваринного походження;

3) позитивно впливати на забарвлення декоративних риб та птахів;

4) задовольняти поживні потреби тварин;

5) позитивно впливати на екологічні наслідки виробництва тваринницької продукції;

6) позитивно впливати на виробництво тваринницької продукції, продуктивність та благополуччя тварин шляхом впливу на шлунково-кишкову флору та засвоюваність кормів;

7) мати кокцидіостатичну або гістомоностатичну дію.

Тобто, для реєстрації кормової добавки необхідно провести дослідження по вивченню ефективності застосування добавки, які підтверджують одну з вищезазначених вимог, в залежності від категорії та функціональної групи та надати відповідні матеріали.

Метою нашої роботи було встановити in vitro ефективність застосування кормової добавки Гепасорбекс, яка відноситься до категорії технологічні добавки та функціональної групи речовини для зменшення забруднення кормів мікотоксинами, шляхом підтвердження іiі здатності стримувати або знижувати поглинання мікотоксинів (зокрема фумонізинів та Т2токсину), сприяти їх виведенню чи змінювати спосіб їх дії.

Матеріали і методи. Дослідження проведено на базі лабораторії контролю кормових добавок та преміксів Державного науково-дослідного контрольного інституту ветеринарних препаратів та кормових добавок. Для проведення досліджень використовували кормову добавку Гепасорбекс виробництва ТОВ «ВЕТСЕРВІСПРОДУКТ». Кормова добавка Гепасорбекс являє собою порошок сірого кольору із специфічним запахом. До складу кормової добавки входить бентоніт, сухі пивні дріжджі, розторопша плямиста. Кормова добавка Гепасорбекс відноситься до категорії технологічних добавки. У межах цієї категорії кормову добавку можна віднести функціональної групи: речовини для зменшення забруднення кормів мікотоксинами - речовини, здатні стримувати або знижувати поглинання мікотоксинів, сприяти їх виведенню чи змінювати спосіб їх дії.

Згідно з вимогами Європейського Союзу [COMMISSION REGULATION (EC) № 429, 2008] та вітчизняних рекомендацій [Kocyumbas et al., 2013], вивчення ефективності технологічних добавок може проводитися in vitro. Тому, нами було проведено вивчення ефективності застосування кормової добавки in vitro стосовно вивчення здатності стримувати або знижувати поглинання мікотоксинів, сприяти їх виведенню, зокрема: фумонізинів та Т2токсину.

Ефективність кормової добавки щодо адсорбції мікотоксинів визначали у відсотках стосовно кількості внесеного (наявного) мікотоксину у досліджуваному зразку та кількістю адсорбованого мікотоксину за дії кормової добавки. При цьому враховували умови перебування корму в шлунково-кишковому тракті тварини (кислий у шлунку та нейтральнолужний у кишечнику).

Практичний коефіцієнт корисної дії (ПККД) визначали з урахуванням різниці між адсорбцією (зв'язуванням) і десорбцією (вивільненням). Чим вищий цей коефіцієнт, тим ефективніша дія кормової добавки - тим більша кількість зв'язаного i, тим самим, дезактивованого мікотоксину. Ефективність специфічної дії кормової добавки визначали кількісно при різних рН, що імітують зміну кислотності середовища в травному каналі тварин. [Malkov et al., 2012, Lysko,2013]. 
Дослідження проводили у два етапи: скринінговий - з використанням кормової добавки Гепасорбекс та розчину мікотоксину та основний - 3 використанням кормової суміші, яка містила мікотоксини та кормової добавки.

На скринінговому етапі кормову добавку Гепасорбекс вносили у буферні розчини із $\mathrm{pH}$ 2, які містили відповідно фумонізин та Т2-токсин у кількості 0,02 \% (200 мкг/л). 0,1 г кормової добавки поміщали у колби. До колб приливали $10 \mathrm{~cm}^{3}$ буферного розчину, інкубували при постійному перемішуванні (з допомогу магнітної мішалки) 1 годину при температурі $37^{\circ} \mathrm{C}$, відокремлювали надосадову рідину від осаду методом центрифугування і визначали в ній вміст фумонізину та Т2-токсину методом ІФА. Після цього вираховували величину адсорбції - загальну кількість зв'язаного мікотоксину за різницею між його кількістю у вихідному розчині та у центрифугаті після інкубування.

До осаду додавали $10 \mathrm{~cm}^{3}$ буферу 3 pH 7,4, інкубували при постійному перемішуванні (з допомогу магнітної мішалки) 3 години при температурі $37^{\circ} \mathrm{C}$, моделюючи $\mathrm{pH}$ середовища i орієнтовний час перебування корму в кишечнику. Надосадову рідину відокремлювали шляхом центрифугування та досліджували на вміст мікотоксинів методом ІФА. Отримували величину десорбції - кількість токсину, звільненого із кормової добавки після інкубації в лужному середовищі.

На другому етапі в попередньо протестовану кормову суміш, яка містила фумонізини та Т2-токсин, вносили досліджувану кормову добавку Гепасорбекс з розрахунку 1, 2, 5 г/кг і ретельно гомогенізували пробу. Попередньо проведеними дослідженнями встановлено, що у досліджуваних зразках міститься 9,4 мг/кг фумонізину та 0,44 мг/кг Т2-токсину. 20 г проби кормової суміші поміщали в конічну колбу До колби приливали $40 \mathrm{~cm}^{3}$ буферного розчину, інкубували при постійному перемішуванні (з допомогу магнітної мішалки) 1 годину при температурі $37^{\circ} \mathrm{C}$, відокремлювали надосадову рідину від осаду методом центрифугування і визначали в ній вміст мікотоксинів методом ІФА. Після цього вираховували величину адсорбції. До осаду додавали $40 \mathrm{~cm}^{3}$ буферу $3 \mathrm{pH}$ 7,4, інкубували при постійному перемішуванні (з допомогу магнітної мішалки) 3 години при температурі $37{ }^{\circ} \mathrm{C}$, моделюючи pH середовища і час перебування корму в кишечнику. Надосадову рідину відокремлювали шляхом центрифугування та досліджували на вміст мікотоксинів методом ІФА. Отримали величину десорбції - кількість токсину, звільненого із кормової добавки після інкубації в лужному середовищі.

Практичний коефіцієнт корисної дії кормової добавки у відсотках стосовно мікотоксинів визначали як різницю між кількістю мікотоксину в досліджуваному зразку та кількістю мікотоксину у надосадовій рідині після інкубації у кислому середовищі 3 врахуванням кількості мікотоксину у надосадовій рідині після інкубації у лужному середовищі. [Vekiru et al., 2007, Fruhaufa et al., 2012, Golovnja, 2014].

Результати й обговорення. Результати дослідження на скринінговому етапі дослідження наведені в таблицях 1 та 2. У таблиці 1 наведено результати стосовно адсорбційних властивостей кормової добавки Гепасорбекс стосовно фумонізину.

Адсорбційні властивості кормової добавки Гепасорбекс стосовно фумонізину

\begin{tabular}{|c|c|c|c|c|}
\hline $\begin{array}{c}\text { Внесено фумонізину, } \\
\text { мкг/мл }\end{array}$ & $\begin{array}{c}\text { Адсорбція } \\
\text { мкг/л }\end{array}$ & $\begin{array}{c}\text { Десорбція } \\
\text { мкг/л }\end{array}$ & $\begin{array}{c}\text { Сумарно адсорбовано } \\
\text { фумонізину, мкг/мл }\end{array}$ & $\begin{array}{c}\text { ПККД, } \\
\%\end{array}$ \\
\hline 200 & 159 & 3 & 156 & 78,0 \\
\hline
\end{tabular}

При внесенні кормової добавки адсорбція фумонізину у кислому середовищі (рН 2) становила 159 мкг/л із внесених 200 мкг/л. Після інкубування у слабо лужному середовищі концентрація фумонізину у надосадовій рідині становила 3 мкг/л. Практичний коефіцієнт корисної дії кормової добавки у скринінговому досліді, враховуючи величину адсорбції та десорбції із становив 78,0\%. 
У таблиці 2 наведено результати стосовно адсорбційних властивостей кормової добавки Гепасорбекс стосовно Т2-токсину.

Адсорбційні властивості кормової добавки Гепасорбекс стосовно Т2 токсину

\begin{tabular}{|c|c|c|c|c|}
\hline $\begin{array}{c}\text { Внесено Т2 } \\
\text { токсину, мкг/мл }\end{array}$ & $\begin{array}{c}\text { Адсорбція } \\
\text { мкг/л }\end{array}$ & $\begin{array}{c}\text { Десорбція } \\
\text { мкг/л }\end{array}$ & $\begin{array}{c}\text { Сумарно адсорбовано Т2 } \\
\text { токсину, мкг/мл }\end{array}$ & $\begin{array}{c}\text { ПККД } \\
\%\end{array}$ \\
\hline 200 & 148 & 7 & 141 & 70,5 \\
\hline
\end{tabular}

Дані таблиці 2, свідчать, що кормова добавка володіє адсорбційною активністю стосовно Т2-токсину. Так, у кислому середовищі (pH 2) адсорбція становила 148 мкг/л Т2токсину із внесених 200 мкг/л, що становить 70,5 \%. Після інкубування у слабо лужному середовищі концентрація мікотоксину у надосадовій рідині становила 7 мкг/л. Тобто, враховуючи величину адсорбції та десорбції, практичний коефіцієнт корисної дії кормової добавки у скринінговому досліді із становив 70,5 \%.

Проведені скринінгові дослідження свідчать, що кормова добавка Гепасорбекс має виражену здатність адсорбувати фумонізини та Т2-токсин і $є$ доцільність проведення подальших досліджень.

При внесенні кормової добавки у кормові суміші на величину адсорбції можуть впливати різні фактори. Тому, для вивчення практичної ефективності кормової добавки в кормах ii вносили у кормову суміш, контаміновану мікотоксинами. Результати вивчення ефективності застосування кормової добавки, внесеної у кормову суміш, контаміновану фумонізином та Т2-токсином, наведено в таблицях 3 та 4.

Таблиия 3

Адсорбційні властивості кормової добавки Гепасорбекс у складі кормової суміші стосовно фумонізину

\begin{tabular}{|c|c|c|c|c|c|}
\hline $\begin{array}{c}\text { Внесено } \\
\text { кормової } \\
\text { добавки, г/кг }\end{array}$ & $\begin{array}{c}\text { Виявлено фумонізину у } \\
\text { кормовій суміші, мг/кг }\end{array}$ & $\begin{array}{c}\text { Адсорбція } \\
\text { мг/кг }\end{array}$ & $\begin{array}{c}\text { Десорбція } \\
\text { мг/кг }\end{array}$ & $\begin{array}{c}\text { Сумарно адсорбовано } \\
\text { фумонізину, мг/кг }\end{array}$ & $\begin{array}{c}\text { ПККД } \\
\%\end{array}$ \\
\hline 1 & 9,4 & 7,0 & 0,5 & 6,5 & 69,1 \\
\hline 2 & 9,4 & 7,2 & 0,5 & 6,7 & 71,2 \\
\hline 5 & 9,4 & 7,4 & 0,6 & 6,8 & 72,3 \\
\hline
\end{tabular}

Внесення кормової добавки Гепасорбекс у різних концентраціях у кормову суміш гарантувало адсорбцію у кислому середовищі (pH 2) 74,5 - 78,7\% фумонізину, від кількості яка була підтверджена на початку дослідження (таблиця 3). Показник десорбції у слабо лужному середовищі $(\mathrm{pH} 7,4)$ становив від 0,5- 0,6 мг/кг, в залежності від кількості внесеної кормової добавки. Враховуючи величину адсорбції та десорбції, практичний коефіцієнт корисної дії кормової добавки Гепасорбекс у досліді становив при внесенні кормової добавки у дозі 1 г/кг 69,1%, при внесенні у дозі 2 г/кг - 71,2 \%, при внесенні у дозі 5 г/кг - 72,3\%.

Таблиия 4

Адсорбційні властивості кормової добавки Гепасорбекс у складі кормової суміші стосовно Т2-токсину

\begin{tabular}{|c|c|c|c|c|c|}
\hline $\begin{array}{c}\text { Внесено } \\
\text { кормової } \\
\text { добавки, г/кг }\end{array}$ & $\begin{array}{c}\text { Виявлено Т2- } \\
\text { токсину у кормовій } \\
\text { суміші, мг/кг }\end{array}$ & $\begin{array}{c}\text { Адсорбція } \\
\text { мг/кг }\end{array}$ & $\begin{array}{c}\text { Десорбція } \\
\text { мг/кг }\end{array}$ & $\begin{array}{c}\text { Сумарно адсорбовано } \\
\text { Т2-токсину, мг/кг }\end{array}$ & $\begin{array}{c}\text { ПККД } \\
\%\end{array}$ \\
\hline 1 & 0,44 & 0,193 & 0,025 & 0,168 & 38,2 \\
\hline 2 & 0,44 & 0,196 & 0,021 & 0,175 & 39,8 \\
\hline 5 & 0,44 & 0,204 & 0,023 & 0,183 & 41,6 \\
\hline
\end{tabular}

Виходячи з даних таблиці 4, враховуючи величину адсорбції та десорбції, практичний коефіцієнт корисної дії у досліді становив при внесенні кормової добавки у дозі 1 г/кг 38,2 \%, при внесенні у дозі 2 г/кг - 39,8 \%, при внесенні у дозі 5 г/кг - 41,6 \%. Відсоток адсорбції Т2 токсину був також суттєво нижчим у порівнянні з фумонізином. 
Результати дослідження показують, що ПККД кормової добавки Гепасорбекс при внесенні у кормову суміш стосовно Т2-токсину та фумонізину був суттєво нижчим, ніж при скринінгових дослідженнях. Це, очевидно, пов'язано з тим, що кормові суміші містять органічні та неорганічні компоненти, які адсорбуються кормовою добавкою, і тим самим знижують іï ефективність стосовно мікотоксину [Levytskyy, 2018].

\title{
В И С Н О В К И
}

1. Проведені дослідження вказують, що кормова добавка Гепасорбекс володіє вираженими адсорбційними властивостями стосовно фумонізинів та Т2 токсину

2. ПККД кормової добавки Гепасорбекс у скринінговому досліді стосовно фумонізинів становив 78,0 \%, стосовно Т2 токсину $-70,5 \%$.

3. ПККД кормової добавки Гепасорбекс при внесенні у кормові суміші у різних дозах стосовно фумонізинів становив 69,1 - 72,3, стосовно Т2 токсину - 38,2 - 41,6 \%. Найбільший ефект досягнуто при внесенні кормової добавки Гепасорбекс у кормові суміші у дозах 2-5 г/кг.

Перспективи досліджень. Проведення випробувань ефективності застосування кормової добавки Гепасорбекс in vitro стосовно інших мікотоксинів, а також проведення випробувань ефективності застосування ефективності застосування in vivo.

\section{EFFICIENCY OF THE TECHNOLOGICAL FEED ADDITIVE HEPASORBEX CONCERNING SOME MICOTOXINS}

\author{
T. R. Levytskyy \\ State Scientific Research Control Institute of Veterinary Medicinal Products and Feed Additives, \\ 11, Donetska str., Lviv, 79019, Ukraine \\ S U M M A R Y
}

It was conducted research under laboratory conditions, concerning the effectiveness of the technological feed additive Hepasorbeks, which belongs to the functional group of substances that reduce the feed contamination by mycotoxins. The objective of our research was to establish in vitro the effectiveness of the feed additive Hepasorbeks by confirming its ability to restrain or reduce the absorption of mycotoxins (fumonisins and T2 toxin). The effectiveness of the specific action of the feed additive was determined quantitatively at various $\mathrm{pH}$ values, simulating a change in the acidity of the medium in the digestive canal of animals. The research was conducted in two stages: screening - using solution of mycotoxin and the main - using compound feed, which contained mycotoxins. At the screening stage, feed additive Hepasorbeks was added to buffer solutions containing, respectively, fumonisins and T2-toxin in an amount of $200 \mathrm{mcg} / \mathrm{g}$. In the main experiment, the feed additive Hepasorbeks was added to the compound feed at the rate of $1,2,5 \mathrm{~g} / \mathrm{kg}$ and the samples were thoroughly homogenized. The absorption magnitude (in an acidic medium) and the desorption magnitude (in an alkaline medium) were determined. The criterion for evaluating the effectiveness was the practical coefficient of efficiency, which was calculated by determining the difference between the amount of inserted mycotoxin and the amount of mycotoxin adsorbed after incubation in an acidic medium, taking into account the value of desorption after incubation in an alkaline medium. It was established that during screening studies, the practical coefficient of efficiency of the feed additive relative to fumonisins was $78,0 \%$, and relative to $\mathrm{T} 2$ toxin was $70.5 \%$. In the main experiment, it was found that the practical coefficient of efficiency of the feed additive depending on the dose was $69,1-72,3 \%$ for fumonisins and 38,2 - 41,6\% for T2 toxin. The findings of investigation confirm that the feed additive Hepasorbeks evinces marked adsorption properties to fumonisins and T2-toxins.

Keywords: T2-TOXIN, FUMONISINS, ADSORPTION, DESORPTION. 


\title{
ЭФФЕКТИВНОСТЬ ПРИМЕНЕНИЯ ТЕХНОЛОГИЧЕСКОЙ КОРМОВОЙ ДОБАВКИ ГЕПАСОРБЕКС ОТНОСИТЕЛЬНО НЕКОТОРЫХ МИКОТОКСИНОВ
}

\author{
T. Р. Левиикий
}

Государственный научно-исследовательский контрольный институт ветеринарных препаратов и кормовых добавок

ул. Донецкая, 11, г. Львов, 79019, Украина

\section{А Н Н О Т А ЦИ Я}

Проведено изучение эффективности применения технологической кормовой добавки Гепасорбекс из функциональной группы веществ для уменьшения загрязнения кормов микотоксинами в лабораторных условиях. Целью работы было установление in vitro эффективности применения кормовой добавки Гепасорбекс путем подтверждения ее способности сдерживать или снижать поглощение микотоксинов (фумонизинов и Т2 токсина). Эффективность специфического действия кормовой добавки определяли количественно при различных значениях $\mathrm{pH}$, имитирующие смену кислотности среды в пищеварительном тракте животных. Исследование проведено в два этапа: скрининговый - с использованием раствора микотоксина и основной - с использованием кормовой смеси, содержащей микотоксины. На скрининговом этапе кормовую добавку Гепасорбекс вносили в буферные растворы, содержащие соответственно фумонизин и Т2-токсин в количестве 200 мкг/л. В основном опыте исследуемую кормовую добавку Гепасорбекс вносили в пробу кормовой смеси из расчета 1, 2, 5 г/кг и тщательно гомогенизировали пробу. Проведено определение величины адсорбции (в кислой среде) и величину десорбции (в щелочной среде). Критерием оценки эффективности был практический коэффициент полезного действия, который рассчитывался путем установления разницы между количеством внесенного микотоксина и количеством адсорбированного микотоксина после инкубации в кислой среде с учетом величины десорбции после инкубации в щелочной среде. Установлено, что при скрининговых исследованиях практический коэффициент полезного действия кормовой добавки относительно фумонизинов составил 78,0\%, относительно Т2 токсина - 70,5\%. В основном опыте установлено, что практический коэффициент полезного действия кормовой добавки в зависимости от дозы составлял относительно фумонизинов 69,1 - 72,3\%, относительно Т2 токсина - 38,2 - 41,6\%. Полученные результаты подтверждают то, что исследуемая кормовая добавка обладает выраженными адсорбционными свойствами по отношению к фумонизинам и Т2-токсину.

Ключевые слова: ФУМОНИЗИН, Т2-ТОКСИН, АДСОРБЦИЯ, ДЕСОРБЦИЯ.

\section{Л I T E P A T У P A}

1. Commission Regulation (EC) № 429/2008 of 25 April 2008 on detailed rules for the implementation of Regulation (EC) No 1831/2003 of the European Parliament and of the Council as regards the preparation and the presentation of applications and the assessment and the authorisation of feed additives (Official Journal of the European Union L 133, 22.5.2008. - P. 60).

2. Fruhaufa S. Yeast cell based feed additives: studies on aflatoxin $B_{1}$ and zearalenone /Sebastian Fruhaufa, Heidi Schwartza, Franz Ottner, Rudolf Krska and Elisavet Vekiru // Food Additives and Contaminants, Vol. 29, No. 2, February 2012, 217-231.

3. Головня Е. Нужно ли оценивать эффективность сорбентов / Комбикорма, № 4, 2014, C. 67-68. 
4. Клінічні дослідження ветеринарних препаратів та кормових добавок: [монографія] / І. Я. Коцюмбас, І. Ю. Бісюк, В. М. Горжеєв [та ін.]; за ред. І. Я. Коцюмбаса. - Л.: ТОВ Видавничий дім «CAM», 2013. - $252 \mathrm{c}$.

5. Левицький T. Р. Ефективність застосування технологічної кормової добавки /Т. Р. Левицький // Науковий вісник ЛНУВММБТ ім. С.З. Гжицького, Серія "Ветеринарні науки", Том 20 № 84. 2017. - С. 142-147.

6. Лыско С.В. Сорбционная активность нового сорбента природного присхождения в отношении Т-2 токсина / Ветеринария и кормление. 2013, № 6, С. 28-29

7. Мікотоксины - стратегия устранения их влияния на организм животных и птицы / Малков М. А, Богомолов В. В., Данкова Т. В., Краснов К. А Ценовик. № 1, 2012, с. 74-75

8. Vekiru E. Investigation of various adsorbents for their ability to bind Aflatoxin $\mathrm{B}_{1} / \mathrm{E}$. Vekiru, S. Fruhauf, M. Sahin, F. Ottner, G. Schatzmayr, R. Krska//Mycotoxin Research Vol. 23, No. 1 (2007), 27-33.

9. Закон України «Про безпеку та гігієну кормів», Голос України, № 12, 19.01.2018/

\section{References}

1. Commission Regulation (EC) № 429/2008 of 25 April 2008 on detailed rules for the implementation of Regulation (EC) No 1831/2003 of the European Parliament and of the Council as regards the preparation and the presentation of applications and the assessment and the authorisation of feed additives (Official Journal of the European Union L 133, 22.5.2008. - P. 60).

2. Fruhaufa S. Yeast cell based feed additives: studies on aflatoxin $B_{1}$ and zearalenone /Sebastian Fruhaufa, Heidi Schwartza, Franz Ottner, Rudolf Krska and Elisavet Vekiru // Food Additives and Contaminants, Vol. 29, No. 2, February 2012, 217-231.

3. Golovnja E. Nuzhno li ocenivat' jeffektivnost' sorbentov / Kombikorma, №4, 2014, s.6768. (in Russian)

4. Kocyumbas I.Ya. Klinichni doslidzhennya vetery`narny'x preparativ ta kormovy`x dobavok/ I.Ya. Kocyumbas, I.Yu.Bisyuk, V.M.Gorzheyev, O.G.Maly’k ta in.. Za red. d-ra vet. nauk, prof. I.Ya. Kocyumbasa L`viv, 2013 - 252 s. (in Ukrainian)

5. Levytskyi T. R. Efektyvnist zastosuvannia tekhnolohichnoi kormovoi dobavky. Naukovyi visnyk LNUVMMBT im. S.Z.Hzhytskoho, Seriia "Veterynarni nauky", Tom 20 № 84. 2018. S. 142147. (in Ukrainian).

6. Lysko S. B. Sorbcionnaja aktivnost' novogo sorbenta prirodnogo proishozhdenija $\mathrm{V}$ otnoshenii T-2 toksina./ Veterinarija i kormlenie. 2013, № 6, s.28-29. ( in Russian)

7. Malkov M.A., Bogomolov V.V., Dan'kova T.V., Krasnov K.A. Mikotoksiny - strategija ustranenija ih vlijanija na organizm sel'skohozjajstvennyh zhivotnyh i pticy / Cenovik, № 1, 2012, s.74-75( in Russian)

8. Vekiru E. Investigation of various adsorbents for their ability to bind Aflatoxin $\mathrm{B}_{1} / \mathrm{E}$. Vekiru, S. Fruhauf, M. Sahin, F. Ottner, G. Schatzmayr, R. Krska//Mycotoxin Research Vol. 23, No. 1 (2007), 27-33.

9. Zakon Ukrayiny` «Pro bezpeku ta gigiyenu kormiv», Golos Ukrayiny`, № 12, 19.01.2018 (in Ukrainian).

Рецензент - I. М. Кушнір, д. вет. н., ДНДКІ ветпрепаратів та кормових добавок. 